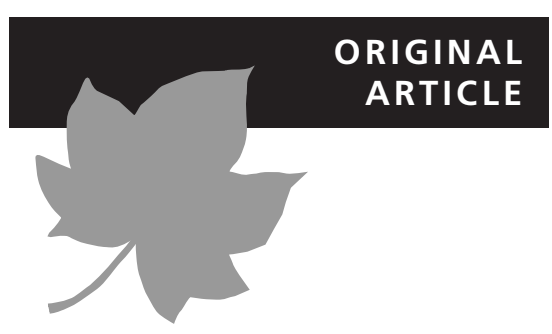

\title{
Testing for biogeographic mechanisms promoting divergence in Caribbean crickets (genus Amphiacusta)
}

\author{
Elen Oneal $^{1}$, Daniel Otte ${ }^{2}$ and L. Lacey Knowles ${ }^{3 *}$
}

${ }^{1}$ Department of Biology, Duke University, 125 Science Drive, Durham, NC 27708, USA, ${ }^{2}$ Academy of Natural Sciences, 1900 Benjamin Franklin Parkway, Philadelphia, PA 19103, USA, ${ }^{3}$ Department of Ecology and Evolutionary Biology, Museum of Zoology, University of Michigan, 1109 Geddes Avenue, Ann Arbor, MI 48109, USA

${ }^{*}$ Correspondence: L. Lacey Knowles, Department of Ecology and Evolutionary Biology, Museum of Zoology, University of Michigan, 1109 Geddes Avenue, Ann Arbor, MI 48109, USA.

E-mail: knowlesl@umich.edu

\section{ABSTRACT}

Aim This work examines whether the history of diversification of Amphiacusta (Orthoptera, Gryllidae) in the Caribbean corresponds to a vicariant or a dispersalist model.

Location The Greater Antillean islands of the Caribbean region.

Methods The phylogenetic relationships among species were estimated using a procedure that directly estimates the underlying species tree from independent loci (in this case, one mitochondrial and one nuclear locus). This tree was then used to test for topological congruence with a vicariant model, and to estimate divergence times.

Results The analyses based on the expected pattern of species divergence (i.e. species-tree topology) support a vicariant model. With the notable exception of a dispersal event marking the colonization of Jamaica, the timing of the events are generally consistent with a vicariant scenario, given the current taxon sampling and potential errors with dating the divergence events.

Main conclusions The tendency of species to co-segregate by island suggests that intra-island diversification is common. Despite their flightlessness, species of Amphiacusta are apparently capable of long-distance dispersal, such as colonization from the Puerto Rican/Virgin Island bank to Jamaica. The topology of the species tree is consistent with a vicariant model of divergence, and the dates of divergence between island groups are generally consistent with an island-island vicariance model. A strict island-island vicariance scenario can, however, be rejected because of inferred dispersal events such as the colonization of Jamaica. Nevertheless, the biogeographic tests suggest that most of the diversity was generated under a combination of intra-island diversification and island-island vicariance. Additional sampling of taxa will be needed to verify this hypothesized scenario. Our findings indicate that Amphiacusta presents an ideal opportunity for examining the role of sexual selection in promoting diversification, which would complement the large number of studies focused on adaptive divergence of Caribbean taxa.

\section{Keywords}

Amphiacusta, Caribbean, dispersal, diversification, Greater Antilles, historical biogeography, island-island vicariance, sexual selection.

\section{INTRODUCTION}

The Caribbean is characterized by a rich and diverse fauna that exhibits high levels of endemism. Numerous attempts have been made over the past several decades to elucidate the means by which this unique fauna emerged (Barbour, 1914; Darlington, 1938; Simpson, 1956; Rosen, 1975; Pregill, 1981; IturraldeVinent \& MacPhee, 1999; Dávalos, 2007), but the region's complex geological history has made it difficult to draw general conclusions about the mechanisms responsible 
(Donnelly, 1989a). Both vicariance (Rosen, 1975; IturraldeVinent \& MacPhee, 1999) and dispersal (Hedges et al., 1992; Hedges, 1996; Heinicke et al., 2007) have been proposed as the predominant forces behind the emergence and diversification of Caribbean taxa. There has also been debate over possible connections between continental mainlands and the Caribbean islands, possibly through emergent islands between North and South America (Donnelly, 1989b, 1990; Pindell \& Barrett, 1990), or a South American connection via a subaerial landspan centred on the Aves Ridge ('GAARlandia') (Iturralde-Vinent \& MacPhee, 1999). Debate also surrounds the timing of emergence and connections between the Greater Antillean islands (Perfit \& Williams, 1989), as well as the role of inter-island diversification in generating the diverse Caribbean fauna - the focus of this study.

Continual tectonic and volcanic activity in the Caribbean basin has resulted in a geological history that is dynamic and complex (Pindell, 1994; Iturralde-Vinent \& MacPhee, 1999), making it difficult to distinguish between dispersal- and vicariance-induced species diversification from geological evidence (Hedges, 2001). Nevertheless, various aspects of the geological history generate explicit predictions about geographic patterns of taxonomic relationships, as well as the timing of diversification. The Lesser Antilles evolved independently from the Greater Antilles, and is composed of two arc systems, one of older islands originating in the late Eocene to Oligocene, and another of younger islands emerging in the late Miocene (MacDonald et al., 2000). The landforms comprising the current islands of Cuba, Hispaniola and Puerto Rico did not begin to emerge until the late Eocene (Pindell, 1994; Robinson, 1994; Iturralde-Vinent \& MacPhee, 1999). Cuba and Hispaniola are both composites of three separate landblocks, and eastern Cuba was connected with northern Hispaniola until the early to mid-Miocene (25-20 Ma) (Pindell \& Barrett, 1990), while the connection between southern and northern Hispaniola was established in the mid-Miocene (Pindell \& Barrett, 1990). The connection between Hispaniola and Puerto Rico was severed c. 16$11 \mathrm{Ma}$ with the formation of Mona Canyon (Iturralde-Vinent \& MacPhee, 1999). During this time Jamaica experienced successive periods of emergence followed by submergence, becoming fully emergent only in the middle Miocene (c. $12 \mathrm{Ma}$; Robinson, 1994). Changes in sea level have also profoundly affected the connections between some islands climatic cycles during the Pliocene and Pleistocene isolated the Virgin Islands from Puerto Rico and resulted in the repeated submergence/emergence of the Bahamas between c. 3 Ma and 118 ka (Hearty \& Neumann, 2001; Reijmer et al., 2002). To the extent that the geological history and associated vicariance events contributed to the species diversity of Caribbean faunas, the signature of this history will be evident in the biogeographic pattern and timing of species divergence (see review by Knowles, 2009).

The vicariance model of Iturralde-Vinent \& MacPhee (1999) proposes that subsequent to the submergence of putative continental connections, formerly widespread taxa diverged allopatrically as islands moved apart during the Oligocene and Miocene. This model predicts that the history of species divergence in the Greater Antilles will reflect the history of island separation. This vicariance model is distinct from that of Rosen (1975), which proposed that current species distributions are the result of vicariant fragmentation of island connections during the Cretaceous - a hypothesis that is refuted by molecular clock estimates of divergence times between Caribbean and mainland taxa (Hedges et al., 1992; Heinicke et al., 2007), and by phylogenies of Caribbean fauna and flora (Malone et al., 2000; Fritsch, 2003; Heinicke et al., 2007).

In contrast, the emergence and diversification of Caribbean taxa may be the result of overwater dispersal from South America, followed by inter-island dispersal and divergence (Hedges et al., 1992; Hedges, 1996). The extent to which island-island vicariance and inter-island dispersal are responsible for shaping the evolutionary history and modern distributions of island taxa remains uncertain (Dávalos, 2004). Although it is clear that dispersal is the only mechanism by which Jamaican taxa could arise (because of its constant isolation from other islands), dispersal among the other islands might also play a role in speciation. However, because such dispersal events would not be constrained to any particular geological period (i.e. the dispersal scenario does not make explicit predictions about the timing and pattern of diversification), the focus of this study is on whether the phylogeny of a group of flightless crickets (genus Amphiacusta) supports a vicariance model of diversification. Specifically, this study tests the timing and pattern of divergence among island groups predicted by island-island vicariance (Fig. 1) using an estimate of the underlying species tree (e.g. Maddison, 1997; Carstens \& Knowles, 2007a; Edwards et al., 2007; Knowles \& Chan, 2008; Kubatko et al., 2009; Liu, 2009; McCormack et al., 2009) derived from the mitochondrial locus cytochrome $c$ oxidase

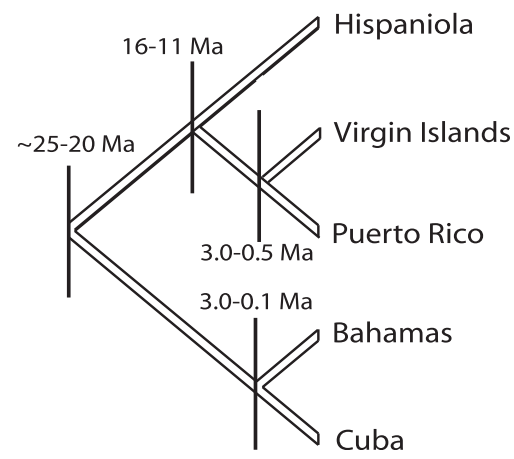

Figure 1 Topology of species relationships of Caribbean Amphiacusta predicted by the island-island vicariance model, with predicted dates of divergence (Iturralde-Vinent \& MacPhee, 1999; MacPhee et al., 2003). The model predicts only the relationships among Cuban, Hispaniolan, Puerto Rican and Virgin Island taxa. Because Jamaica was emergent only by the mid-Miocene (c. $12 \mathrm{Ma}$ ) (Robinson, 1994) its fauna must have arisen by dispersal, and is therefore not included in the model. 
subunit I (COI) and the nuclear locus elongation factor 1-alpha $(\mathrm{EF} 1-\alpha)$.

Amphiacusta (Saussure, 1874) is a genus of ground crickets restricted to the Caribbean and constitutes the largest portion of Neotropical diversity in the Phalangopsinae (Orthoptera, Gryllidae) - a subfamily that is distributed world-wide. There are more than 80 described species of Amphiacusta, most of which are found in the Greater Antilles and are endemic to one island (Desutter-Grandcolas \& Otte, 1997; Otte \& PerezGelabert, 2009). The species are nocturnal and occur in a variety of habitats, including sandy beaches, wet and dry tropical forest, and caves. All species in this family are flightless, a feature which may hinder inter-island colonization by dispersal and make inter-island vicariance and intra-island speciation more likely (e.g. Mendelson \& Shaw, 2005; Carstens \& Knowles, 2007b). This reduced potential for dispersal coupled with the impressive diversity of Amphiacusta means that the genus may provide insights into how the complex geological history may have contributed to species diversification in this biodiversity hotspot.

\section{MATERIALS AND METHODS}

\section{Sampling}

Twenty-eight species in the genus Amphiacusta and a codistributed outgroup in the same family, Yoyuteris phacodes, were sampled (Table 1, Fig. 2). This sampling constitutes c. $35 \%$ of described species, with sampling particularly dense in Hispaniola, Puerto Rico and the Virgin Islands (i.e. the targeted study region). We consider the implications of our sampling in the Discussion. All specimens are located in the Knowles Lab at the University of Michigan Museum of Zoology, Ann Arbor, MI, USA, or the Academy of Natural Sciences, Philadelphia, PA, USA. The specimen awaiting formal description (i.e. species 1) exhibits significant differen-

Table 1 Locality information for studied specimens of the genus Amphiacusta and a co-distributed outgroup in the same family, Yoyuteris phacodes. The undescribed species from Puerto Rico is referred to as Amphiacusta species 1.

\begin{tabular}{|c|c|c|c|}
\hline Species & Locality & Island & ID no. \\
\hline Amphiacusta henrymorgani ${ }^{1}$ & Henry Morgan's Cave, Andros Town & Bahamas & UMMZ E174 \\
\hline Amphiacusta ruizi ${ }^{2}$ & Los Morenos, Santiago Prov. & Cuba & ANS 3183 \\
\hline Amphiacusta sincerus $^{3}$ & Holquin Prov. & Cuba & UMMZ E18 \\
\hline Amphiacusta mythica ${ }^{4}$ & Ebano Verde, La Vega Prov. & NE Hispaniola (Dom. Rep.) & UMMZ E175 \\
\hline Amphiacusta hespera ${ }^{4}$ & Loma Guaconejo, Sanchez Prov. & NE Hispaniola (Dom. Rep.) & ANS 2603 \\
\hline Amphiacusta annulipes ${ }^{4}$ & Ebano Verde, La Vega Prov. & NE Hispaniola (Dom. Rep.) & ANS RD-021 \\
\hline Amphiacusta apoplanos ${ }^{5}$ & La Ciénaga, Barahona Prov. & SW Hispaniola (Dom. Rep.) & UMMZ E169 \\
\hline Amphiacusta dapanera ${ }^{4}$ & Sierra de Neiba, Barahona Prov. & SW Hispaniola (Dom. Rep.) & ANS 2608 \\
\hline Amphiacusta dimalea ${ }^{6}$ & Parque Nacional Jaragua, Pedernales Prov. & SW Hispaniola (Dom. Rep.) & ANS RD-156 \\
\hline Amphiacusta domingensis ${ }^{4}$ & Sierra de Neiba, Barahona Prov. & SW Hispaniola (Dom. Rep.) & UMMZ E164 \\
\hline Amphiacusta eritheles ${ }^{6}$ & Padre Las Cases, Azua Prov. & SW Hispaniola (Dom. Rep.) & ANS RD-122 \\
\hline Amphiacusta exacerbans ${ }^{6}$ & Sierra de Neiba, Barahona Prov. & SW Hispaniola (Dom. Rep.) & ANS RD-110 \\
\hline Amphiacusta expansa $a^{4}$ & Sierra Martin Garcia, Azua Prov. & SW Hispaniola (Dom. Rep.) & ANS 2575 \\
\hline Amphiacusta extenta ${ }^{4}$ & Parq. Nac. Armando Bermúdez, La Vega Prov. & SW Hispaniola (Dom. Rep.) & ANS RD-49 \\
\hline Amphiacusta ominosa ${ }^{4}$ & Monte Rio, Azua Prov. & SW Hispaniola (Dom. Rep.) & UMMZ E171 \\
\hline Amphiacusta pomeriense ${ }^{4}$ & La Ciénaga, Barahona Prov. & SW Hispaniola (Dom. Rep.) & UMMZ E170 \\
\hline Amphiacusta sterna ${ }^{4}$ & Rojo-Aceitillar, Pedernales Prov. & SW Hispaniola (Dom. Rep.) & UMMZ E173 \\
\hline Yoyuteris phacodes ${ }^{4}$ & Sierra Martin Garcia, Azua Prov. & SW Hispaniola (Dom. Rep.) & UMMZ E22 \\
\hline Amphiacusta aetheria ${ }^{7}$ & Mano Matuey, San Cristobal Prov. & SE Hispaniola (Dom. Rep.) & ANS RD-002 \\
\hline Amphiacusta obstipa ${ }^{5}$ & Puerto Escondido, Altagracia Prov. & SE Hispaniola (Dom. Rep.) & UMMZ E172 \\
\hline Amphiacusta opsia ${ }^{4}$ & Matadero, Peravia Prov. & SE Hispaniola (Dom. Rep.) & ANS RD-053 \\
\hline Amphiacusta nauta ${ }^{8}$ & Mandeville, Cockpit Country & Jamaica & UMMZ J5-6-1 \\
\hline Amphiacusta pronauta 9 & El Yunque & Puerto Rico & UMMZ PR1-5-2 \\
\hline Amphiacusta lares ${ }^{8}$ & Lares & Puerto Rico & UMMZ PR1-6-1 \\
\hline Amphiacusta viequesense ${ }^{8}$ & Viequez Island & Puerto Rico & UMMZ PR7-6-1 \\
\hline Amphiacusta species $1^{9}$ & Cerro Las Piñas & Puerto Rico & UMMZ PR1-5-4 \\
\hline Amphiacusta tijicohniae ${ }^{8}$ & Guanica & Puerto Rico & UMMZ PR3-6-1 \\
\hline Amphiacusta hyperphobos ${ }^{6}$ & Guana Island & Virgin Islands & UMMZ E157 \\
\hline Amphiacusta sanctaecrucis & Rain forest, Rte. 76, Saint Croix & Virgin Islands (US) & UMMZ STC5-2 \\
\hline
\end{tabular}

NE, north-eastern; SE, south-eastern; UMMZ, University of Michigan Museum of Zoology; ANS, Academy of Natural Sciences, Philadelphia.

${ }^{1}$ Collected by D. Otte. ${ }^{2}$ Collected by A. Infante. ${ }^{3}$ Collected by A. E. Ruiz and D. Otte. ${ }^{4}$ Collected by D. Perez-Gelabert, R. Bastardo and B. Hierro.

${ }^{5}$ Collected by D. Perez-Gelabert and R. Bastardo. ${ }^{6}$ Collected by D. Otte and D. Perez-Gelabert. ${ }^{7}$ Collected by D. Otte, D. Perez-Gelabert and

R. Bastardo. ${ }^{8}$ Collected by D. Otte, L. L. Knowles, E. Oneal and H. Huang. ${ }^{9}$ Collected by D. Otte, L. L. Knowles and E. Oneal. 


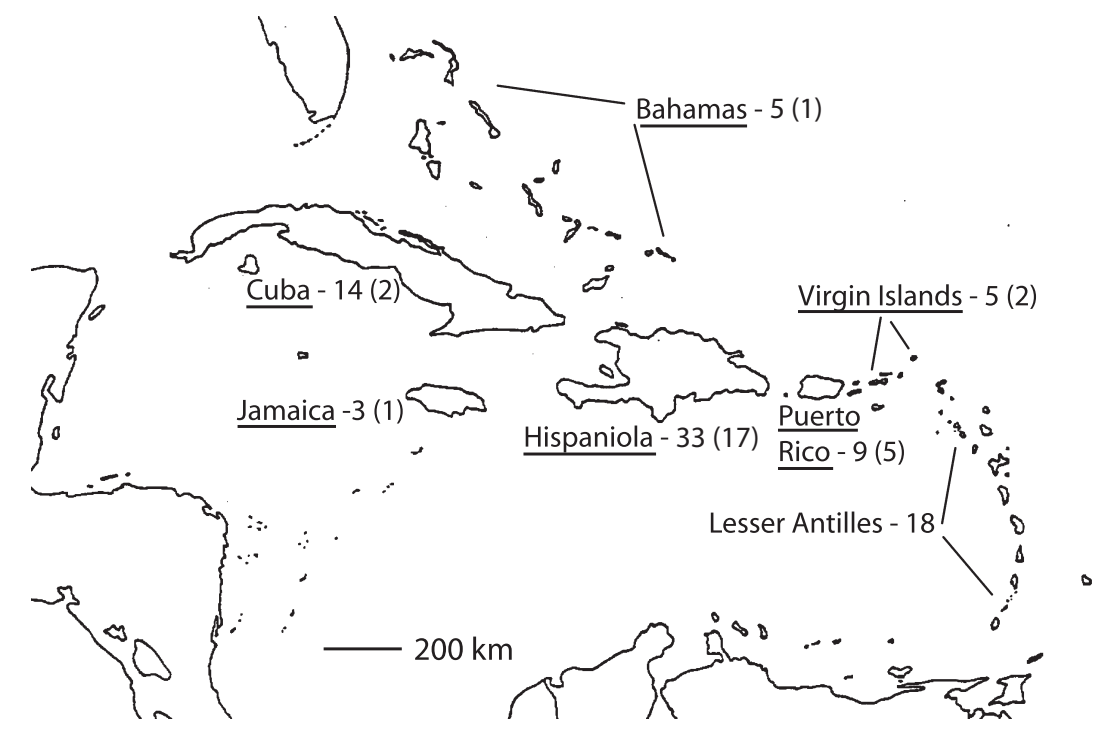

Figure 2 Map of the Caribbean with the number of endemic Amphiacusta taxa (first number) for each of the largest islands and the smaller island chains. The names of the islands included in the study are underlined and the numbers of species sampled are given in parentheses.

tiation in the morphology of its genitalia, the primary distinguishing feature among species in this genus.

Genomic DNA was extracted from the femur of each individual using a Qiagen DNeasy kit (Qiagen, Valencia, CA, USA). A 1185-base pair (bp) fragment of the mitochondrial locus COI and a 900-bp fragment of the nuclear EF1- $\alpha$ were sequenced (see Table 2 for primers and Knowles, 2000, for the PCR protocol). Sequences can be found in GenBank under accession numbers EU939163-EU939220; the standard genetic code for degenerate sites was used for heterozygous sites in EF1$\alpha$ (18 sites in 12 species). Both strands of each product were sequenced on an ABI Model 3730 sequencer (Applied Biosystems, Foster City, CA, USA). All sequences were aligned using Sequencher 3.1 (Gene Codes, Ann Arbor, MI, USA) and Clustal; EF1- $\alpha$ sequences were readily aligned by eye as well.

\section{Phylogenetic analysis}

Maximum likelihood (ML) in PAUP ${ }^{\star} 4.0$ (Swofford, 2002), as well as a Bayesian analysis using MrBAyes 3.0 (Ronquist \&

Table 2 A list of primers used for cytochrome $c$ oxidase subunit I (COI) and elongation factor 1-alpha $(\mathrm{EF} 1-\alpha)$. All primers are written $5^{\prime}-3^{\prime}$. PCR protocols are found in Knowles (2000).

\begin{tabular}{lll}
\hline Gene & Primer & Sequence \\
\hline COI & C1-J-1718-2 & GGA-GGA-TTY-GGA-AAT-TGA-TTA-GTW-CC \\
& L2-N-3014 & TCC-ATT-GCA-CTA-ATC-TGC-CAT-ATT-A \\
& C1-J-2183 & CAA-CAT-TTA-TTT-TGA-TTT-TTT-GG \\
& C1-N-2191 & CCC-GGT-AAA-ATT-AAA-ATA-TAA-ACT-TC \\
EF1- $\alpha$ & EF1-F1 & AGA-TGG-GYA-ARG-GTT-CCT-TCA-A \\
& EF1-R1 & GAA-CAC-CAG-TCT-CCA-CAC-GA \\
& EF1-AF4 & AGA-TGG-GYA-ARG-GTT-CCM-TCM-A \\
& EF1-BF2 & TCG-TTT-CGA-GGA-AAT-MAA-GAA \\
& EF1-BR3 & TGG-CAC-TGT-TCC-AAT-ACC-AC \\
\hline
\end{tabular}

Huelsenbeck, 2003), was used to estimate a gene tree for each locus, and to determine whether concatenation of these two loci was appropriate. For the ML analyses, 25 random addition replicates and tree bisection-reconnection (TBR) branch swapping were used for each data set with a maximum of 100 trees saved; branch support was evaluated with nonparametric ML bootstrapping, with 100 random addition replicates limited to 10 trees each. Four Markov chains of 5.5 million generations were used in the Bayesian analyses, with trees sampled every 1000 generations; posterior branch probabilities were calculated after excluding the first 0.5 million generations. Convergence was assessed by confirming the consistency of the results across two independent runs, as well as plotting the $\log$ likelihood of the trees against the number of generations to determine that the log likelihood of trees had plateaued. A HKY $+\mathrm{I}+\mathrm{G}$ model of sequence evolution for COI (Hasegawa et al., 1985) (base frequencies $\mathrm{A}=0.3610$, $\mathrm{C}=0.1966, \mathrm{G}=0.0611, \mathrm{~T}=0.3818$, transition/transversion ratio $=8.09, \alpha=0.81$, and proportion invariant sites $=0.58)$, and a Tamura-Nei+G model of evolution for EF1- $\alpha$ (Tamura $\&$ Nei, 1993) (base frequencies $\mathrm{A}=0.2931, \mathrm{C}=0.1670$, $\mathrm{G}=0.2309, \mathrm{~T}=0.3090$, rate matrix $\mathrm{rAC}=1, \mathrm{rAG}=2.17$, $\mathrm{rAT}=1, \mathrm{rCG}=2.17, \mathrm{rCT}=3.81, \mathrm{rGT}=1$ and $\alpha=0.30$ ) were used in the phylogenetic analyses (gaps were not included in the phylogenetic analyses); these models were identified by the program DT ModSel (Minin et al., 2003) based on a comparison of likelihood scores among possible models of evolution.

Recent studies have identified potential problems with concatenation of multiple loci for phylogenetic analysis (e.g. concatenated data may not allow accurate inferences of the species history; Kubatko \& Degnan, 2007). For any particular history of divergence, there is also no way of knowing whether the estimated tree from concatenated data matches the underlying species history (Maddison \& Knowles, 2006). Moreover, the approximately unbiased (AU) test (Shimodaira, 
2002) identified significant incongruence between the estimated gene trees, confirming that concatenation would be inappropriate. This approach involves the comparison of $P$-values for individual gene tree estimates that are calculated based on a site-wise log-likelihood value. Therefore, we chose to estimate the species tree directly using the program BEST (Bayesian estimation of species trees; Liu, 2009), which jointly estimates the gene trees and species trees under a Bayesian framework. Priors for the gene trees were based on the models of evolution selected by DT ModSel. Convergence was assessed by plotting the gene tree length against the number of generations for each locus, and the log likelihood against the number of generations for the estimated species tree. Consistency of the results was confirmed across two independent runs, with 50 million Markov chain Monte Carlo (MCMC) generations per run.

\section{Test of biogeographic hypotheses}

Since inter-island vicariance makes predictions about the relationships among island groups, but not within islands, only the branching sequence among islands was considered in this test [i.e., the following relationships: (Cuba, Bahamas), (Hispaniola (Puerto Rico, Virgin Islands))]. Although fossils would ideally be used to calibrate the divergence times estimated from phylogenies (Smith \& Peterson, 2002), such data are not available. In addition to the scarcity of orthopteran fossils (Poinar, 1993, 1999), controversy surrounds the age of insect fossils collected in the region (Grimaldi, 1995). For example, dates range from 15-20 Ma (Iturralde-Vinent \& MacPhee, 1996) to 25-40 Ma (Poinar, 1993) for fossils from amber in the Dominican Republic, depending on the method used and the source of amber. Estimates of the timing of divergence were derived from the estimated species tree. Branch lengths in species trees produced in BEST are expressed as the number of substitutions per site or $\mu T$, where $\mu$ is the mutation rate and $T$ is the number of generations (Liu, 2009); as locus-specific estimated models of nucleotide substitution were used in these analyses, species tree branch lengths inherently take into account differences in the substitution models of COI and EF1- $\alpha$. To estimate an absolute divergence time for nodes of interest (e.g. the timing of divergence between Hispaniolan and Cuban taxa) the species tree branch lengths were divided by the mutation rate of the arthropod mitochondrial genome $\left(1.1 \times 10^{-8}\right)$ as derived by Brower (1994), which is commonly used for dating divergence events in insects (e.g. Carisio et al., 2004; Kölsch \& Pedersen, 2008; Carletto et al., 2009). A range of divergence times was calculated, which corresponds to two to three generations per year (based on field observations, as well as generation times in the laboratory).

\section{RESULTS}

The average length of EF1- $\alpha$ sequence was $841 \mathrm{bp}$, of which 234 were variable. Of $1185 \mathrm{bp}$ of the COI sequence, 470 were variable. Absolute sequence divergence within the ingroup ranged from $0 \%$ to $9.1 \%$ for $\mathrm{EF} 1-\alpha$, and $0.09 \%$ to $21.4 \%$ for COI. The divergence between the ingroup and outgroup taxa (Yoyuteris phacodes) ranged from $16.2 \%$ to $20.4 \%$ for EF1- $\alpha$ and $18.7 \%$ to $20.7 \%$ for COI.

The primary incongruence between the COI and EF1- $\alpha$ gene trees, in terms of topological differences relevant to the biogeographic hypotheses of interests, is the placement of the Cuban and Bahaman taxa (Figs $3 \& 4$ ). Nevertheless, the gene trees estimated for COI and EF1- $\alpha$ also exhibit some broad similarities, most of which are reflected in the species tree estimated by BEST (Fig. 5). In the species tree, taxa from Puerto Rico, the Virgin Islands and Jamaica form a clade with Amphiacusta tijicohniae and Amphiacusta species 1 basal to the rest of the more recently derived taxa. Species also tend to co-segregate by island, although only Hispaniolan taxa formed a well-supported monophyletic clade. The Cuban species (Amphiacusta ruizi and Amphiacusta sincerus) and the Bahaman species Amphiacusta henrymorgani formed a clade that was basal to all other taxa, although with weak nodal support. The Jamaican species Amphiacusta nauta derived from a clade comprising Puerto Rican and Virgin Island taxa. The topology of the species tree was consistent with a vicariant history of diversification.

The divergence times derived from the species tree place the divergence of the Cuban-Bahaman group from all other taxa at c. 16.3-10.9 Ma, while the split between the Hispaniolan clade and the Puerto Rican-Virgin Island taxa occurs very soon afterwards, around 15.6-0.4 Ma. The split between the Bahaman species $A$. henrymorgani and the Cuban species A. ruizi and A. sincerus corresponds to a divergence around 3.0-2.0 Ma. Amphiacusta species 1, which is basal to the Puerto Rican taxa, split off around 11.4-7.6 Ma. The speciation events within the group of Virgin Island, Puerto Rican and Jamaican taxa that are sister to Amphiacusta tijicohniae all appear to have occurred recently and rapidly. For example, the divergence of Amphiacusta sanctaecrucis from Amphiacusta hyperphobos is very recent, and occurred around 123-82 ka, while the dispersal event that led to the Jamaican species A. nauta occurred c. 478-319 ka.

\section{DISCUSSION}

Emerging evidence suggests roles for both vicariance and dispersal as mechanisms promoting diversification of Caribbean taxa. The importance of overwater dispersal has been demonstrated in a range of taxa, including reptiles (Hedges et al., 1992; Malone et al., 2000), amphibians (Hedges et al., 1992; Heinicke et al., 2007), mammals (Dávalos, 2007) and plants (McDowell \& Bremer, 1998; Negrón-Ortiz \& Watson, 2002; Lavin et al., 2003; McDowell et al., 2003). Nevertheless, it is likely that vicariance has also played a role, and in some cases support for both processes has been found (Lavin et al., 2003; McDowell et al., 2003; Brandley \& de Quieroz, 2004). Similarly, interplay between these two mechanisms is evidenced by the phylogenetic relationships within Amphiacusta, 
Figure 3 Estimated gene tree for Caribbean Amphiacusta from a maximum likelihood analysis of cytochrome $c$ oxidase subunit I (COI) under an $\mathrm{HKY}+\mathrm{I}+\mathrm{G}$ with base frequencies $\mathrm{A}=0.3610, \mathrm{C}=0.1966$, $\mathrm{G}=0.0611, \mathrm{~T}=0.3818$, transition/transversion ratio $=8.09, \alpha=0.81$ and proportion of invariant sites $=0.58$. ${ }^{\star}$ Bayesian posterior probabilities $\geq 95 \%$.

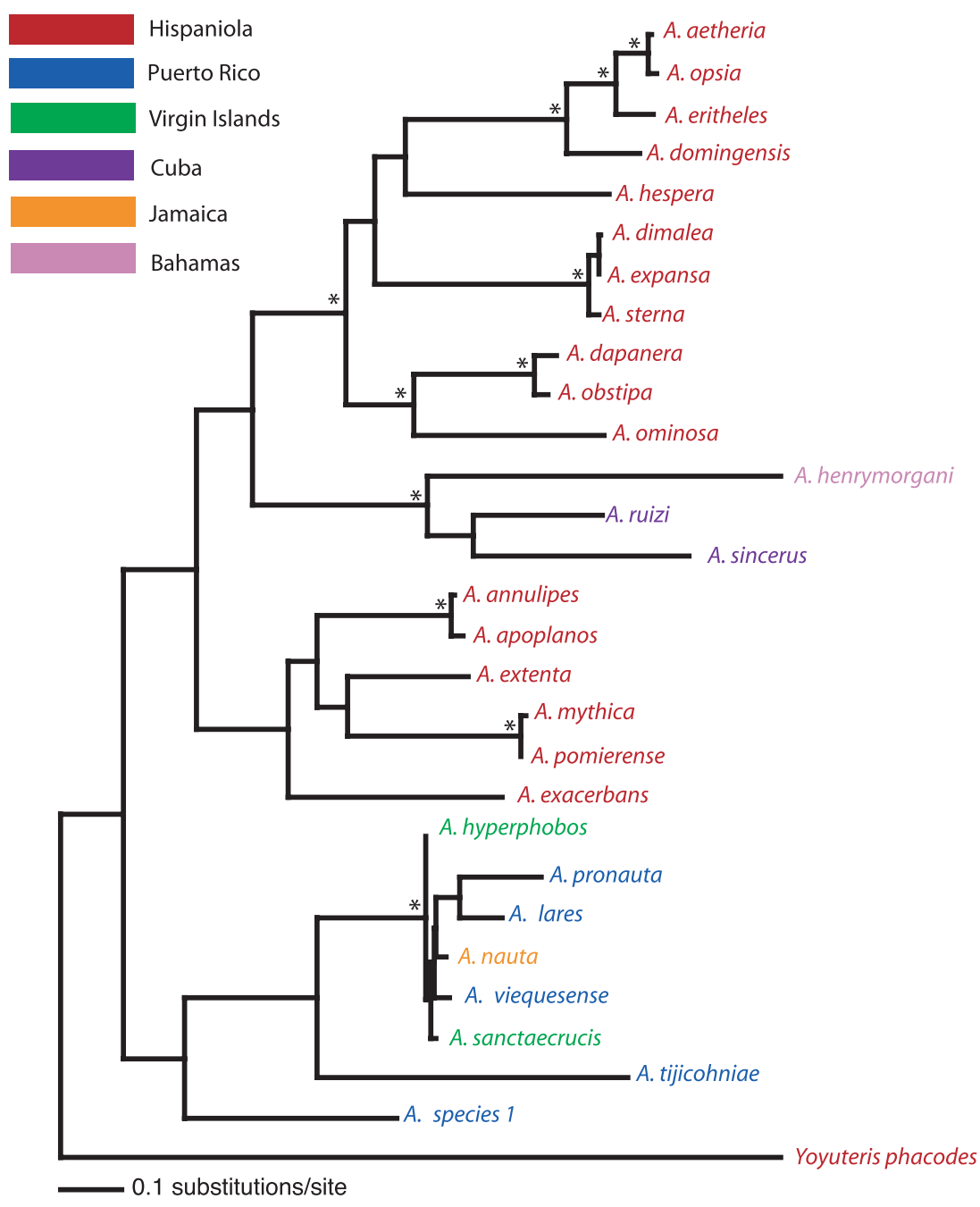

but dispersal does not appear to play a major role. However, the predominance of intra-island diversification and islandisland vicariance needs confirmation with additional sampling of taxa.

The timing of divergences between Puerto Rican and Virgin Island taxa within the last million years suggests a history of vicariance resulting from the rise in sea level during the Pleistocene, severing populations that then diverged in allopatry, and is consistent with the recency of separation among those islands (Heatwole \& MacKenzie, 1967). At the same time, the derivation of the Jamaican species A. nauta from Puerto Rico is clear evidence of long-distance dispersal. Despite their flightlessness, the ocean does not constitute a complete barrier to dispersal for these crickets. While such dispersal events over long distances may seem counterintuitive, release and recapture experiments with buoys have demonstrated that flotsam can drift across large distances in the Caribbean and may take a meandering course affected by prevailing currents and storm conditions (Molinari et al., 1979). Furthermore, observations for a range of taxa, including insects, indicate that rafting on floating vegetation (Holzapfel \& Harrell, 1968; Censky et al., 1998) may result in successful colonization events. Nevertheless, this one example involving the colonization of Jamaica by Amphiacusta suggests that successful colonization by dispersal may indeed be quite rare for these crickets.

While the tests for topological congruence allow for the possibility of vicariance among the islands of Hispaniola and Puerto Rico, there is some ambiguity in the data. The placement of the Cuban-Bahaman group as basal to all the other taxa supports the inter-island vicariance model; however, this node does not show strong support (Fig. 5). Furthermore, the timing of divergence is not entirely consistent with predictions of island-island vicariance. For example, the split of the Cuban-Bahaman group from the rest of the islands dates to 16.3-10.9 Ma, which is more recent than the predicted divergence of 25-20 Ma from the model (Fig. 1). However, this discrepancy is not so extreme as to suggest that it is outside the margin of error associated with estimating branch lengths in the species tree, especially given that estimates of older divergences may be prone to greater errors (Edwards et al., 2007). The timing of divergence of Hispaniolan taxa from the Puerto Rican-Virgin Island group at 15.6-10.4 Ma, however, is consistent with vicariance. Interestingly, the 


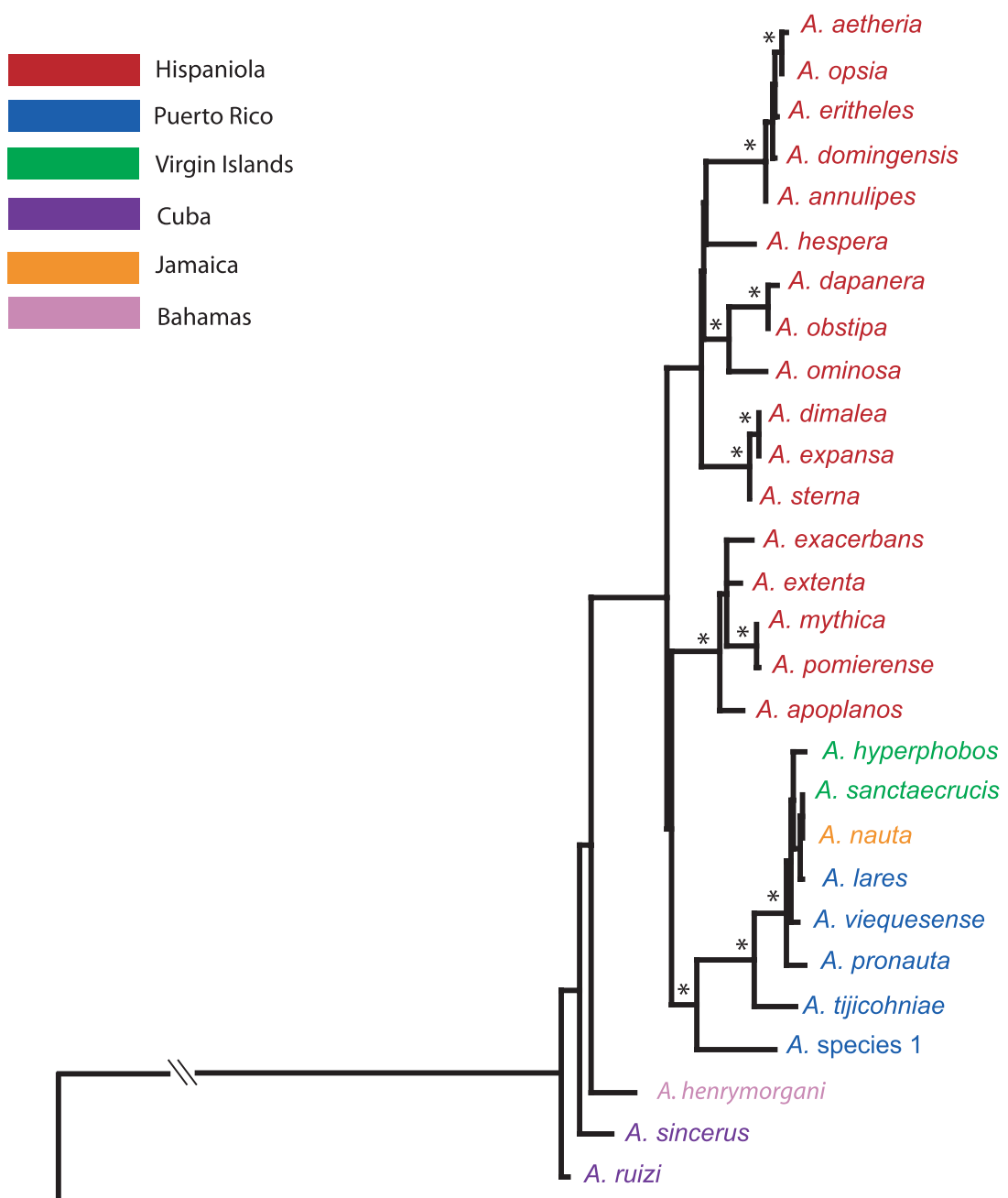

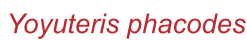

- 0.01 substitutions/site

finding that A. henrymorgani diverged from A. ruizi and A. sincerus, a split of a Bahaman taxon from Cuban taxa c. 3.0-2.0 Ma, is much older than expected if Pleistocene fluctuations of sea level drove speciation in that area (Hearty \& Neumann, 2001). However, other researchers have found evidence for similarly deep divergences between Bahaman and Cuban taxa (Glor et al., 2005), which suggest the possibility of refugia among the Bahaman islands (Glor et al., 2005). Our result may also reflect errors in the estimated branch lengths of the species trees (e.g. variance in the estimate of the population-mutation parameter, $\theta$, would affect the branch lengths of the species tree; Kubatko et al., 2009; Liu, 2009).

In addition to a basal relationship between Cuban and other Greater Antillean taxa, a close affinity between eastern Cuban and northern and central Hispaniolan taxa has been taken as evidence for vicariance (McDowell et al., 2003) because of the historical connections between these landmasses; however, we do not see this pattern in our data. The Hispaniolan clade sister to the Cuban/Bahaman clade is composed of species occurring in each of the north-eastern, south-western and south-eastern parts of Hispaniola (see Table 1). Amphiacusta from these regions do not co-segregate, suggesting that intraisland diversification on Hispaniola may have occurred following the collision in the mid-Miocene (c. $15 \mathrm{Ma}$ ) between the landmasses that now comprise the southern and northern portions of the island (Graham, 2003). It must be noted that limited sampling of Cuban taxa makes it difficult to draw definitive conclusions about vicariance versus dispersal in this case. Cuba is the largest island and probably hosts a diversity of Amphiacusta species. The two Cuban species sampled are representatives from two out of the five different species groups defined by Otte \& Perez-Gelabert (2009) on the basis of morphological, and specifically genitalic, differences. Therefore, while only a small proportion of the Cuban species were sampled, the sampling does at least encompass some of the breadth of species diversity found on the island. Nevertheless, additional sampling will be key to confirming the biogeographic scenario supporting vicariance in the estimated species tree (Fig. 5). Similarly, while the pattern of species splitting is consistent with vicariance (Fig. 1), with the limited sampling (both taxa and loci) the timing of divergence estimated from the species tree makes it difficult to rule out a possible role for 


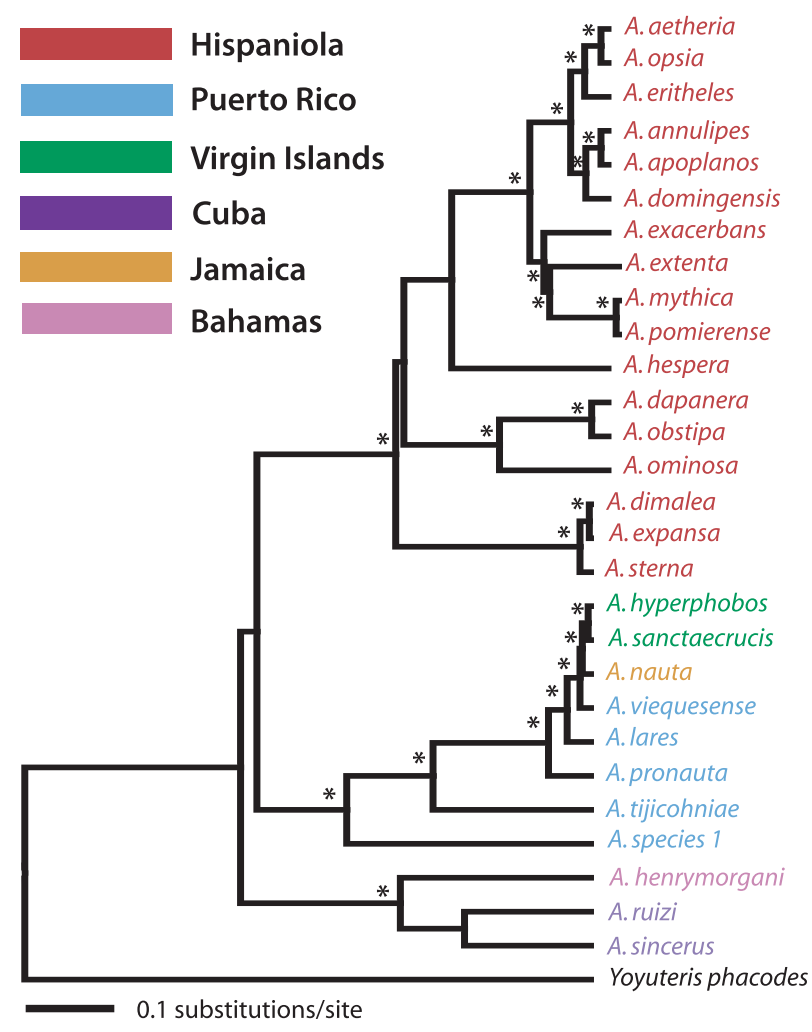

Figure 5 Species tree for Caribbean Amphiacusta estimated from the Bayesian program BEST (Liu, 2009). ${ }^{\star}$ Bayesian posterior probabilities $\geq 95 \%$.

dispersal (i.e. while the divergence times are more recent than expected, errors for these deeper divergence dates are possible, as discussed above).

This is one of a few studies on the historical biogeography of terrestrial invertebrates in the Caribbean (see also Davies \& Bermingham, 2002; Wilder \& Hollocher, 2003; Brisson et al., 2006; Velez \& Feder, 2006). Most work on the biogeography of Caribbean fauna has focused on vertebrates (Ricklefs \& Bermingham, 2004; Glor et al., 2005; Perdices et al., 2005; Dávalos, 2007; Heinicke et al., 2007). Furthermore, several studies have investigated the ecological mechanisms and evolutionary dynamics driving the diversification of Caribbean fauna (Warheit et al., 1999; Wilder \& Hollocher, 2003; Langerhans et al., 2006). Given that the analyses support a history of vicariance, with a limited role for dispersal, as well as a preponderance of intra-island diversification (in the case of Hispaniola and Puerto Rico), it is worthwhile to investigate what factors other than historical biogeography may have resulted in the great diversity of Amphiacusta. The substantial differences in male genital morphology among species raises the possibility that sexual selection on male genitalia, often suggested to promote the evolution of species diversity (Eberhard, 1985; Arnqvist, 1998), may play a role in diversification in this group. For example, the divergences between A. hyperphobos and A. sanctaecrucis and between Virgin Island and Puerto Rican species Amphiacusta viequesense all appear to be very recent, occurring within the last 478,000-
319,000 years. Yet, the species in this clade differ significantly in shape of the male genitalia at both the species and population level (E. Oneal, unpublished data), suggesting that selection has played a role in the diversification of the crickets (e.g. Masta \& Maddison, 2002; Marquez \& Knowles, 2007). With its island distribution and history of intra-island diversification, Amphiacusta presents an opportunity to examine the role of sexual selection in promoting diversification that would complement the large number of studies focused on the adaptive divergence of Caribbean taxa.

\section{CONCLUSIONS}

Tests of the biogeographic history of Amphiacusta support a predominant role for vicariance among islands and intraisland diversification, paralleling the movements of the Greater Antilles islands since the Oligocene. Specifically, an estimated species tree based on analyses of two independent molecular markers suggests a history of long-distance dispersal in the colonization of Jamaica that led to the formation of the Jamaican species $A$. nauta, with both the timing and pattern of divergence supporting a possible variance event separating the Hispaniolan and Puerto Rican clades, accompanied by in situ diversification within Hispaniola and Puerto Rico, as well as vicariant separation between Virgin Island and Puerto Rican taxa resulting from Pleistocene changes in sea level.

There are several limitations to our analysis. Our species tree is based on only two genes, and a lack of fossil evidence means that we must rely on previously published mutation rates (Brower, 1994). Moreover, while the estimation of the species tree accounts for variance between gene trees in the estimation of branch lengths, there remains some intrinsic variance in the estimation of branch lengths for more ancestral taxa (Edwards et al., 2007). This, coupled with the limited sampling of taxa from Cuba (because of limited access), makes it difficult to rule out the possibility that the taxon sampled from Cuba might represent a secondary colonization from Hispaniola, while other Cuban species actually fit a vicariance model. However, as a clearer picture about the geographic and geological context of species diversification emerges with additional sampling of species (and perhaps loci), Caribbean crickets will provide a unique opportunity to investigate the role of sexual selection in promoting diversification, as the primary patterns of divergence in Amphiacusta are found in sexual characters and not in ecological traits, as is commonly found for other Caribbean taxa.

\section{ACKNOWLEDGEMENTS}

We are grateful to D. Perez-Gelabert, R. Bastardo, B. Hierro, A. E. Ruiz, A. Infante and H. Huang for the collection of samples, and to D. Perez-Gelabert for the loan of several specimens from the Dominican Republic. We also thank Bryan Carstens for helpful discussion of phylogenetic methods. Robert Payne, Bryan Carstens and John McCormack provided comments on a previous draft of this manuscript, as did referees for this 
journal. Financial support was provided by Rackham Graduate School (University of Michigan) and Society of Systematic Biology grants to E.O., and a National Science Foundation grant (DEB-07-15487) to L.L.K.

\section{REFERENCES}

Arnqvist, G. (1998) Comparative evidence for the evolution of genitalia by sexual selection. Nature, 393, 784-786.

Barbour, T. (1914) A contribution to the zoogeography of the West Indies, with especial reference to amphibians and reptiles. Memoirs of the Comparative Museum of Zoology, 44, 209-359.

Brandley, M.C. \& de Quieroz, K. (2004) Phylogeny, ecomorphological evolution, and the historical biogeography of the Anolis cristatellus series. Herpetological Monographs, 18, 90126.

Brisson, J.A., Wilder, J. \& Hollocher, H. (2006) Phylogenetic analysis of the cardini group of Drosophila with respect to changes in pigmentation. Evolution, 60, 1228-1241.

Brower, A.V.Z. (1994) Rapid morphological radiation and convergence among races of the butterfly Heliconius erato inferred from patterns of mitochondrial DNA evolution. Proceedings of the National Academy of Sciences USA, 91, 6491-6495.

Carisio, L., Cervella, P., Palestrini, C., DelPero, M. \& Rolando, A. (2004) Biogeographical patterns of genetic differentiation in dung beetles of the genus Trypocopris (Coleoptera, Geotrupidae) inferred from mtDNA and AFLP analyses. Journal of Biogeography, 31, 1149-1162.

Carletto, J., Lombaert, E., Chavigny, P., Brévault, T., Lapchin, L. \& Vanlerberghe-Masutti, F. (2009) Ecological specialization of the aphid Aphis gossypii Glover on cultivated host plants. Molecular Ecology, 18, 2198-2212.

Carstens, B.C. \& Knowles, L.L. (2007a) Estimating species phylogeny from gene-tree probabilities despite incomplete lineage sorting: an example from Melanoplus grasshoppers. Systematic Biology, 56, 1-12.

Carstens, B.C. \& Knowles, L.L. (2007b) Shifting distributions and speciation: species divergence during rapid climate change. Molecular Ecology, 16, 619-627.

Censky, E.J., Hodge, K. \& Dudley, J. (1998) Over-water dispersal of lizards due to hurricanes. Nature, 395, 556.

Darlington, P.J. (1938) The origin of the Greater Antilles, with discussion of dispersal of animals over water and the air. Quarterly Review of Biology, 13, 274-300.

Dávalos, L.M. (2004) Phylogeny and biogeography of Caribbean mammals. Biological Journal of the Linnaean Society, 81, 373-394.

Dávalos, L.M. (2007) Short-faced bats (Phyllostomatidae: Stenodermatina): a Caribbean radiation of strict frugivores. Journal of Biogeography, 34, 364-375.

Davies, N. \& Bermingham, E. (2002) The historical biogeography of two Caribbean butterflies (Lepidoptera: Heliconiidae) as inferred from genetic variation at multiple loci. Evolution, 56, 573-589.
Desutter-Grandcolas, L. \& Otte, D. (1997) Revision of the West Indian genus Amphiacusta Saussure, 1874, with descriptions of twenty new species (Orthoptera: Grylloidea: Phalangopsidae). Annales de la Societé Entomologique de France, 33, 101-128.

Donnelly, T.W. (1989a) Geologic history of the Caribbean and Central America. The geology of North America-an overview, Vol. A (ed. by A.W. Bally and A.R. Palmer), pp. 299-321. Geological Society of America, Boulder, CO.

Donnelly, T.W. (1989b) History of marine barriers and terrestrial connections: Caribbean paleogeographic inference from pelagic sediment analysis. Biogeography of the West Indies: past, present, and future (ed. by C.A. Woods), pp. 103-117. Sandhill Crane Press, Inc., Gainesville, FL.

Donnelly, T.W. (1990) Pelagic sediment, deep water chemistry, and tectonics: an application of the history of biological sediment accumulation on the tectonic history of the Caribbean. Rivista Italiana di Paleontologica e Stratigrafia, Milano, 96, 143-164.

Eberhard, W.G. (1985) Sexual selection and animal genitalia. Harvard University Press, Cambridge, MA.

Edwards, S.V., Liu, L. \& Pearl, D.K. (2007) High-resolution species trees without concatenation. Proceedings of the National Academy of Sciences USA, 104, 5936-5941.

Fritsch, P.W. (2003) Multiple geographic origins of Antillean Styrax. Systematic Botany, 28, 421-430.

Glor, R.E., Losos, J.B. \& Larson, A. (2005) Out of Cuba: overwater dispersal and speciation among lizards in the Anolis carolinensis subgroup. Molecular Ecology, 14, 24192432.

Graham, A. (2003) Geohistory models and Cenozoic paleoenvironments of the Caribbean region. Systematic Botany, 28, 378-386.

Grimaldi, D.A. (1995) Amber, resinite, and fossil resins. ACS Symposium, 617, 203-217.

Hasegawa, M., Kishino, H. \& Yano, T. (1985) Dating the human-ape split by a molecular clock of mitochondrial DNA. Journal of Molecular Evolution, 22, 160-174.

Hearty, P.J. \& Neumann, A.C. (2001) Rapid sea level and climate change at the close of the Last Interglaciation (MIS 5e): evidence from the Bahama islands. Quaternary Science Reviews, 20, 1881-1895.

Heatwole, H. \& MacKenzie, F. (1967) Herpetogeography of Puerto Rico. IV. Paleogeography, faunal similarity and endemism. Evolution, 21, 429-438.

Hedges, S.B. (1996) Historical biogeography of West Indian vertebrates. Annual Review of Ecology and Systematics, 27, 163-196.

Hedges, S.B. (2001) Biogeography of the West Indies: an overview. Biogeography of the West Indies: patterns and perspectives (ed. by C.A. Woods and F.E. Sergile), pp. 15-33. CRC Press, Washington, DC.

Hedges, S.B., Hass, C.A. \& Maxson, L.R. (1992) Caribbean biogeography: molecular evidence for dispersal in West 
Indian terrestrial vertebrates. Proceedings of the National Academy of Sciences USA, 89, 1909-1913.

Heinicke, M.P., Duellman, W.E. \& Hedges, S.B. (2007) Major Caribbean and Central American frog faunas originated by ancient oceanic dispersal. Proceedings of the National Academy of Sciences USA, 104, 10092-10097.

Holzapfel, E.P. \& Harrell, J.C. (1968) Transoceanic dispersal studies of insects. Pacific Insects, 10, 115-153.

Iturralde-Vinent, M.A. \& MacPhee, R.D.E. (1996) Age and paleogeographical origin of Dominican amber. Science, 273, 1850-1852.

Iturralde-Vinent, M.A. \& MacPhee, R.D.E. (1999) Paleogeography of the Caribbean region: implications for Cenozoic biogeography. Bulletin of the American Museum of Natural History, 238, 1-95.

Knowles, L.L. (2000) Tests of Pleistocene speciation in montane grasshoppers from the sky islands of western North America (genus Melanoplus). Evolution, 54, 1337-1348.

Knowles, L.L. (2009) Statistical phylogeography. Annual Review of Ecology and Systematics, 40, 593-612.

Knowles, L.L. \& Chan, Y.-H. (2008) Resolving species phylogenies of recent evolutionary radiations. Annals of the Missouri Botanical Garden, 95, 224-231.

Kölsch, G. \& Pedersen, B.V. (2008) Molecular phylogeny of reed beetles (Col., Chrysomelidae, Donaciinae): the signature of ecological specialization and geographical isolation. Molecular Phylogenetics and Evolution, 48, 936-952.

Kubatko, L.S. \& Degnan, J.H. (2007) Inconsistency of phylogenetic estimates from concatenated data under coalescence. Systematic Biology, 56, 17-24.

Kubatko, L., Carstens, B. \& Knowles, L.L. (2009) STEM: species tree estimation using maximum likelihood for gene trees under coalescence. Bioinformatics, 25, 971-973.

Langerhans, R.B., Knouft, J.H. \& Losos, J.B. (2006) Shared and unique features of diversification in greater Antillean Anolis ecomorphs. Evolution, 60, 362-369.

Lavin, M., Wojciechowski, M.F., Gasson, P., Hughes, C. \& Wheeler, E. (2003) Phylogeny of robinioid legumes (Fabaceae) revisited: Coursetia and Gliricidia recircumscribed, and a biogeographical appraisal of the Caribbean endemics. Systematic Botany, 28, 387-409.

Liu, L. (2009) BEST: Bayesian estimation of species trees under the coalescent model. Bioinformatics, 24, 2542-2543.

MacDonald, R., Hawkesworth, C.J. \& Heath, E. (2000) The Lesser Antilles volcanic chain: a study in arc magmatism. Earth Science Reviews, 49, 1-76.

MacPhee, R.D.E., Iturralde-Vinent, M.A. \& Gaffney, E.S. (2003) Domo de Zaza, an early Miocene vertebrate locality in south-Middle Cuba, with notes on the tectonic evolution of Puerto Rico and the Mona Passage. American Museum Novitates, 3394, 1-42.

Maddison, W.P. (1997) Gene trees in species trees. Systematic Biology, 46, 523-536.

Maddison, W.P. \& Knowles, L.L. (2006) Inferring phylogeny despite incomplete lineage sorting. Systematic Biology, 55, 21-30.
Malone, C.L., Wheeler, T., Taylor, J.F. \& Davis, S.K. (2000) Phylogeography of the Caribbean rock iguana (Cyclura): implications for conservation and insights on the biogeographic history of the West Indies. Molecular Phylogenetics and Evolution, 17, 269-279.

Marquez, E.J. \& Knowles, L.L. (2007) Correlated evolution in multivariate traits: detecting codivergence across multiple dimensions. Journal of Evolutionary Biology, 20, 2334-2348.

Masta, S.E. \& Maddison, W.P. (2002) Sexual selection driving diversification in jumping spiders. Proceedings of the National Academy of Sciences USA, 99, 4442-4447.

McCormack, J.E., Huang, H. \& Knowles, L.L. (2009) Maximum-likelihood estimates of species trees: how accuracy of phylogenetic inference depends upon the divergence history and sampling design. Systematic Biology, doi: 10.1093/ sysbio/syp045.

McDowell, T. \& Bremer, B. (1998) Phylogeny, diversity, and distribution in Exostema (Rubiaceae): implications of morphological and molecular analyses. Plant Systematics and Evolution, 212, 215-246.

McDowell, T., Volovsek, M. \& Manos, P. (2003) Biogeography of Exostema (Rubiaceae) in the Caribbean region in light of molecular phylogenetic analyses. Systematic Botany, 28, 431441.

Mendelson, T.C. \& Shaw, K.L. (2005) Rapid speciation in an arthropod. Nature, 433, 275-376.

Minin, V., Abdo, Z., Joyce, P. \& Sullivan, J. (2003) Performance-based selection of likelihood models for phylogeny estimation. Systematic Biology, 52, 674-683.

Molinari, R.L., Atwood, D.K., Duckett, D., Spillane, M. \& Brooks, I. (1979) Surface currents in the Caribbean Sea as deduced from satellite tracked drifting buoys. Proceedings of the Gulf Caribbean Fisheries Institute, 1979, 106-113.

Negrón-Ortiz, V. \& Watson, L.E. (2002) Molecular phylogeny and biogeography of Erithalis (Rubiaceae), an endemic of the Caribbean basin. Plant Systematics and Evolution, 234, 71-83.

Otte, D. \& Perez-Gelabert, D. (2009) Caribbean crickets. Orthopterists' Society, Ann Arbor, MI.

Perdices, A., Doadrio, I. \& Bermingham, E. (2005) Evolutionary history of the synbranchid eels (Teleostei: Synbranchidae) in Central American and the Caribbean islands inferred from their molecular phylogeny. Molecular Phylogenetics and Evolution, 37, 460-473.

Perfit, M.R. \& Williams, E.E. (1989) Geological constraints and biological retrodictions in the evolution of the Caribbean Sea and its islands. Biogeography of the West Indies (ed. by C.A. Woods), pp. 47-102. Sandhill Crane Press, Gainesville, FL.

Pindell, J.L. (1994) Evolution of the Gulf of Mexico and the Caribbean. Caribbean geology: an introduction (ed. by S.K. Donovan and T.A. Jackson), pp. 13-40. University of West Indies Publishers' Association, Kingston, Jamaica.

Pindell, J.L. \& Barrett, S.F. (1990) Geological evolution of the Caribbean region: a plate-tectonic perspective. The geology of 
North America, Vol. H, The Caribbean region (ed. by G. Dengo and J.E. Case), pp. 405-432. Geological Society of America, Boulder, CO.

Poinar, G.O. (1993) Insects in amber. Annual Review of Entomology, 46, 145-159.

Poinar, G.O. (1999) The amber forest: a reconstruction of a vanished world. Princeton University Press, Princeton, NJ.

Pregill, G.K. (1981) An appraisal of the vicariance hypothesis of Caribbean biogeography and its application to West Indian terrestrial vertebrates. Systematic Zoology, 30, 147155.

Reijmer, J.J.G., Betzler, C., Kroon, D., Tiedemann, R. \& Eberli, G.P. (2002) Bahamian carbonate platform development in response to sea-level changes and the closure of the Isthmus of Panama. International Journal of Earth Science, 91, 482489.

Ricklefs, R.E. \& Bermingham, E. (2004) History and the species-area relationship in Lesser Antillean birds. The American Naturalist, 163, 227-239.

Robinson, E. (1994) Jamaica. Caribbean geology: an introduction (ed. by S.K. Donovan and T.A. Jackson), pp. 87-110. University of West Indies Publishers' Association, Kingston, Jamaica.

Ronquist, F. \& Huelsenbeck, J.P. (2003) MRBAYES 3: Bayesian phylogenetic inference under mixed models. Bioinformatics, 19, 1572-1574.

Rosen, D.E. (1975) The vicariance model of Caribbean biogeography. Systematic Zoology, 24, 431-464.

Shimodaira, H. (2002) An approximately unbiased test of phylogenetic tree selection. Systematic Biology, 51, 492-508.

Simpson, G.G. (1956) Zoogeography of West Indian land mammals. American Museum of Natural History Novitates, 1759, 1-28.

Smith, A.B. \& Peterson, K.J. (2002) Dating the time of origin of major clades: molecular clocks and the fossil record. Annual Review of Earth and Planetary Sciences, 30, 65-88.

Swofford, D.L. (2002) PAUP*. Phylogenetic analysis using parsimony ( ${ }^{*}$ and other methods). Version 4. Sinauer Associates, Sunderland, MA.

Tamura, K. \& Nei, M. (1993) Estimation of the number of nucleotide substitutions in the control region of mito- chondrial DNA in humans and chimpanzees. Molecular Biology and Evolution, 10, 512-526.

Velez, S. \& Feder, J.L. (2006) Integrating biogeographic and genetic approaches to investigate the history of bioluminescent colour alleles in the Jamaican click beetle, Pyrophorus plagiophthalamus. Molecular Ecology, 15, 1393-1404. Warheit, K.I., Forman, J.D., Losos, J.B. \& Miles, D.B. (1999) Morphological diversification and adaptive radiation: a comparison of two diverse lizard clades. Evolution, 53, 12261234.

Wilder, J.A. \& Hollocher, H. (2003) Recent radiation of endemic Caribbean Drosophila of the dunni subgroup inferred from multilocus DNA sequence variation. Evolution, 57, 2566-2579.

\section{BIOSKETCHES}

Elen Oneal is a recent graduate from the University of Michigan, where she investigated the biogeographic and evolutionary mechanisms driving divergence in Amphiacusta at both the species and population level, with an emphasis on morphological divergence. She is now a post-doctoral researcher at Duke University.

Daniel Otte is Curator of Insects at the Academy of Natural Sciences in Philadelphia, PA, USA, and a leading authority on the systematics of Orthoptera. His interests include the taxonomy of orthopteran taxa and their patterns of morphological and acoustic divergence.

L. Lacey Knowles is an Associate Professor and Curator of Insects at the University of Michigan. Her research focuses on the demographic and selective processes driving species divergence, as well as the methodological and statistical issues involved in studying species diversification and phylogeography.

Editor: Bradford Hawkins 